\title{
Revision of the Money Supply Series
}

\author{
by ALBERT E. BURGER
}

HE RECENT REVISION by the Federal Reserve System of the statistical series on the amount of currency and demand deposits held by the nonbanking public consisted of two major parts. The largest part of the revision was made in August and involved adjusting the demand deposit component of the money supply. This revision was necessary to correct for an understatement of demand deposits, which had arisen from an increasing volume of cash items generated by a rapidly growing volume of Eurodollar transactions. The second part of the revision, first available on September 25, included the incorporation of new benchmark data for nonmember bank demand deposits and holdings of vault cash ${ }^{1}$ and the anmual review of the seasonal adjustment factors for the demand deposit and currency components of the money supply.

\section{When Is a Revision Necessary?}

The collecting, processing, and maintaining of any series of data involve the allocation of scarce resources for that purpose. These data are not free goods; they involve an opportunity cost. One major justification for the cost of collecting data on demand deposits and currency is that such data provide useful information for policy-making purposes. There is a well-developed theoretical framework that includes as its focal point the stock of money balances held by the nonbanking public. This theoretical framework and considerable empirical evidence indicate that changes in the magnitude of the money stock have important implications for the future course of economic activity.

1Benchmark data refer to data from call reports which all commercial banks are required to provide at least twice a year to the major agencies charged with regulating commercial banks.
When economists draw implications about the direction of economic activity, based upon observations of movements in the statistical series called the money supply, they assume that the data measure what the series was defined to measure. If the data no longer accurately represent the same concept as that upon which the conclusions of theory and empirical evidence are based, then there is a real danger that the consequences predicted by applying the theory will not occur.

A revision of a basic series that either improves the data's representation of the concept it is supposed to represent, or makes it more comparable with past data on which empirical results have been derived, can only be viewed as being beneficial to the users of the series. Such a revision was necessitated this year by a change in bank behavior.

\section{Reasons for the Revision}

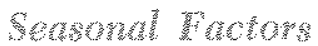

Most weekly, monthly, and quarterly economic time series are subject to recurrent seasonal factors. To view movements of the series free of seasonal distortions, economic data are frequently seasonally adjusted by some method such as the $\mathrm{X}-11$ computer program developed by the Bureau of the Census, Seasonal adjustment factors applying to the money stock are revised to take into account any changes that have occurred in the usual seasonal pattern of the public's holdings of demand deposits and currency.

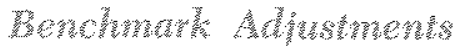

Deposits and vault cash holdings of nonmember banks must be estimated between semi-annual call of condition reports. The use of new benchmark data provides added information on these items for 
nonmember banks, and hence permits a more accurate measurement of total demand deposits and currency held by the nonbanking public. The June 1969 benchmark data adjusted primarily the demand deposit component of the money supply series resulting in an addition of $\$ 400$ million to money supply growth over the first half of 1969.2

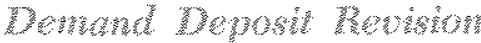

The demand deposit component of the money supply includes only demand deposits of the public, that is, demand deposits at all commercial banks other than those due to domestic commercial banks and the U.S. Government, less cash items in process of collection. A simple example will explain why cash items are deducted:

Suppose Mr. A writes a check for $\$ 100$ on his bank $\mathrm{CB}_{\mathrm{A}}$. He then gives the check to $\mathrm{Mr}$. B who deposits it in his bank $\mathrm{CB}_{\mathrm{B}}$. While the check (item) is in process of collection, it appears as a demand deposit in both $\mathrm{CB}_{A}$ and $\mathrm{CB}_{B}$. Due to an institutional constraint which prevents instantaneous check clearing, gross demand deposits rise by $\$ 100$.

Mr. A knows that he no longer holds $\$ 100$ in his checking account. Since the purpose of the money supply series is to measure the currency and demand deposits held by the public, which the public knows it holds, we must deduct the cash item in process of collection (the $\$ 100$ check of $\mathrm{Mr}$. A) to get an accurate measure of the size of the quantity we want to measure with our statistical series.

Before July 31, 1969, the rapidly growing volume of drafts used in transferring or repaying Eurodollar borrowings, usually referred to as "bills payable checks" and "London checks", were not included in gross demand deposits by the issuing bank. However, these drafts were included in the cash items of the foreign branch of the bank, and as such were deducted from gross demand deposits of the domestic bank.

Since member banks' reserve requirements are calculated on the basis of net demand deposits (i.e. gross demand deposits minus cash items in process of collection and demand balances due from domestic banks), inclusion of London checks and bills payable checks lowered their required reserves. These transactions did not involve any double counting of demand deposits held by the public, yet they operated to reduce the demand deposit component of the

2The data for time deposits at all commercial banks were also revised using the new benchmark data and seasonal factors. The June 1969 benchmark data added $\$ 800$ million to nonmember bank time deposit growth during the first half of 1969 . money supply, and the data representing the money supply was biased downward. The actual holdings of demand deposits by the public were greater than reported in the money supply data.

Effective July 31, 1969, under a revision of Federal Reserve Regulation $D$, the issuing banks are required to include bills payable checks and London checks used in repayment and borrowing of Eurodollars in gross demand deposits as well as in cash items in process of collection. To take into account the impact of this change in banks' actions on the reporting of money supply figures prior to August 1969, the demand deposit component of money was revised by the Federal Reserve System.

\section{Has the Revision of the Money Supply Series Substantially Revised Conclusions Based on its Use?}

To consider this question, we shall examine three money supply series for three recent periods of time: (1) the money supply series as reported before Angust; (2) the money supply series as revised in early August, which included estimated revisions in the old money supply series, and (3) the new money supply series available in the week of September 25, which includes seasonal and benchmark revisions. ${ }^{3}$ The three periods considered are December 1967 to December 1968, December 1968 to early June 1969, and early June 1969 to early September 1969.

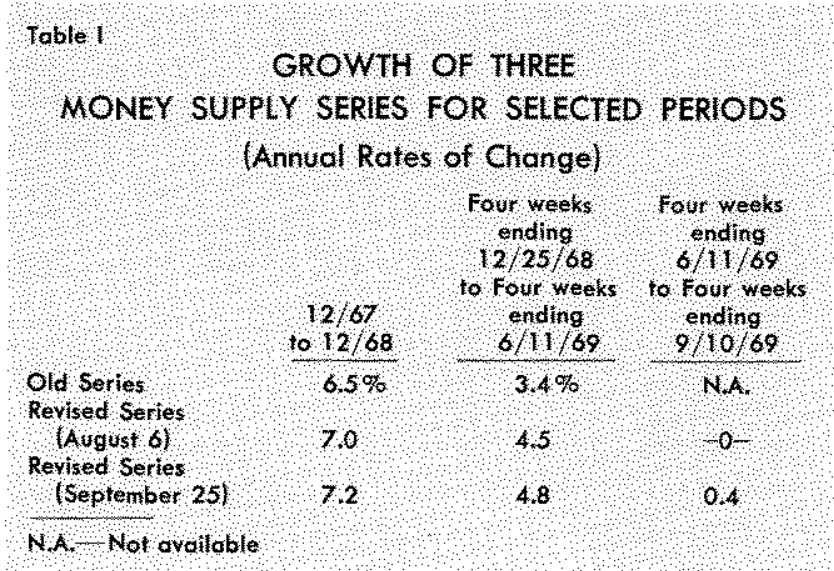

Comparing the old money supply and demand deposit series with the revised series of September 25 in Tables I and II, the major difference is that both new series show faster growth rates during 1968 and the first half of 1969. Both the old and new revised series show the same pattern of changes in the growth

3The September 25 revision of the money supply is referred to as the "new money supply series" only as an aid in exposition. 


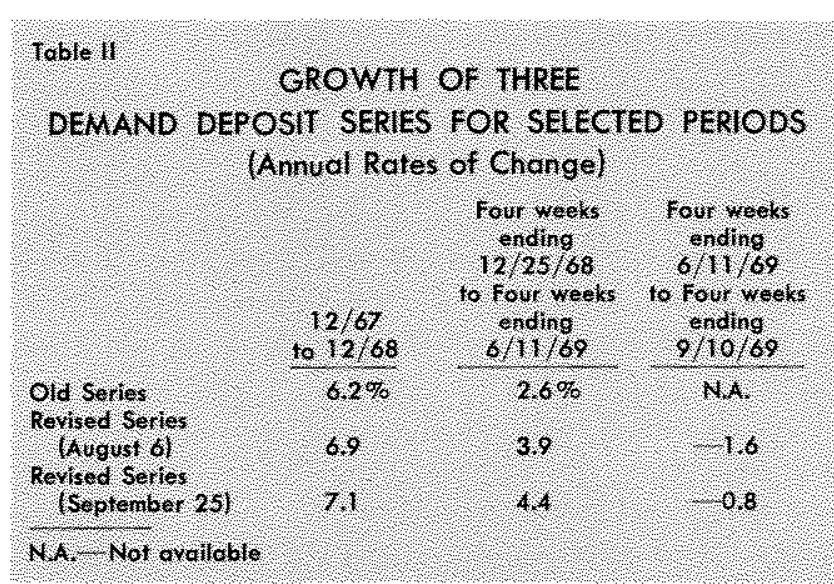

rate of money, a slowing in the first half of 1969 compared to 1968 . The new revised series shows a less pronounced slowing in the growth rate of money and demand deposits over the first half than was shown by the old series.

\section{算賞在 A A}

In early August the first revised money supply series became available to policymakers. This series pointed out that money and demand deposits had grown somewhat faster over the first part of 1969 than the old money supply data had indicated. Also, with the preliminary adjustments for changes in the demand deposit series, the annual rate of increase of demand deposits for 1968 rose from 6.2 per cent to 6.9 per cent. Hence, the growth of the money supply for this period was also adjusted upward from an annual rate of 6.5 per cent to 7 per cent.

The August series was only an interim measure until new benchmark data could be included, and new seasonal factors calculated. However, the August revision moved a long way toward pointing out the difference in trends between the old money supply series and the new money supply series which became available on September 25.

The August series was used until late September, when the completed new series became available. ${ }^{4}$ Comparing the August series and the new series for the period from mid-year through early September, we see that the new data show slightly less of a slowing in the annual rate of increase of money and demand deposits than was indicated by the August revision. However, whether one looks at the new series or the August series, the pattern of monetary developments is very much the same. Both sets of

4 The money supply revision released on September 25 included revised data for the money supply beginning January 1967. Minor revisions of the data for recent years prior to 1967 will be avalable in late October or early Novenber. data reveal a marked decrease in the rate of growth of money and the demand deposit component of money since mid-year.

Would a person, who used the money supply data in 1969 as a guide to the influence of monetary actions on the future course of economic activity, have made a major change in his interpretation of the direction of these influences as new data became available? Comparing the pattern of movements of the three series on money, it seems that only over the first half of 1969 could the observer of money supply data have been misled by the unrecognized impact of changed bank behavior on the reported data. Using the old money supply data until late summer, an observer of the money supply would have concluded there had been a decided slowing in the monetary impulses transmitted to the economy since December 1968. When the revised series became available in August, he would have modified his views on the actual severity of the slowing in the money supply, but he would have maintained the belief that there had been some reduction in the magnitude of monetary influences on the economy. Using the August revision, an observer of the money supply would have concluded that there was a much sharper decrease in the rate of monetary expansion about midyear. The new data available in September did not significantly alter this view.

\section{Effects of Revisions in the Money Supply Series on Forecasting the Impact of Monetary Influences on GNP}

An increasing body of empirical evidence supports the conjecture that during past time periods, changes in the rate of change of the magnitude of the money stock have been the dominant factor in determining the future course of economic activity. When attempting to determine the probable impact of monetary policy on spending for final goods and services, this empirical evidence is extremely useful. One means of forecasting the impact of monetary influences on GNP using past and projected changes of the money supply is to use a reduced-form forecasting equation which directly telates changes in GNP to changes in money.

One such equation was developed by Leonall $\mathrm{C}$. Andersen and Jerry Jordan, not primarily for forecasting purposes, but to test certain assertions about the relative magnitude and speed with which monetary and fiscal actions affect GNP. ${ }^{5}$ The use of this

5Leonall C. Andersen and Jerry L. Jordan, "Monetary and Fiscal Actions: A Test of Their Relative Importance in Economic Stabilization," this Review, November 1968, pp. 11-24. 
equation as a forecasting device requires a projection of the future growth rates of money and high-employment expenditures. It also requires the use of past data on money supply and expenditures. A question that may be posed is: If past data are substantially revised, does this seriously affect GNP forecasts based on this type of forecasting equation?

To answer this question, the Andersen-jordan equation was run using the data from each of the three money supply series and, for illustrative purposes, an annual growth rate of 2 per cent for money from the second quarter 1969 through the second quarter of 1970 was assumed. The results for predicted annual rates of change of GNP and dollar changes in GNP are given in Table III.

Examining Table III we see that the major mpact of the revision of money supply data is on GNP projections for the third and fourth quarters of 1969. In July 1969, when projecting the growth of GNP for the remainder of 1969 , the use of the old money supply series would have given a slower projected growth of GNP than would have been predicted by the use of the September money supply data. However, the projected growth rate of economic activity in the first two quarters of 1970 was not significantly different than what would be projected in mid-September after all revisions in the money supply data were completed.

In August, when the first revision in the money supply data was completed, a new run of the An-

6Using this equation and the actual data from the new money supply series, the average difference between the actual dollar change in GNP and the dollar change in GNP predicted by the equation for the six quarters I/1968 through II/1969 was only $\$ 1.4$ billion.

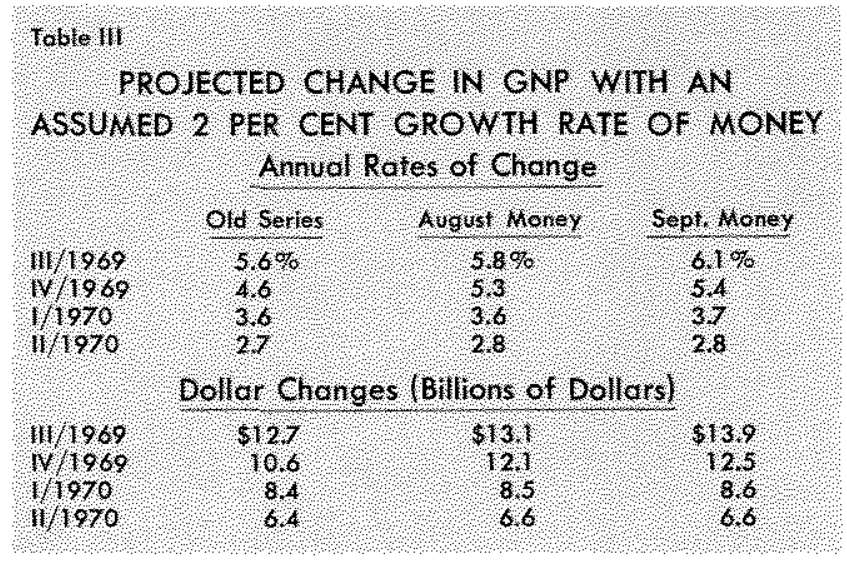

dersen-Jordan equation would have corrected most of the discrepancy. The projection for fourth quarter 1969 using the August revision of money supply data would still have been somewhat lower than using the September revision. However, the projections made in August 1969 for growth rates of GNP in the last quarter of 1969 and through the first half of 1970 would have been almost identical to the projections possible after September 25 using the latest revision in the money supply data.

The projected dollar change of GNP from II/1969 through II $/ 1970$ would be $\$ 38.1$ billion using the old money supply data, $\$ 40.3$ billion using the August revision and $\$ 41.6$ billion using the late September money supply data. The difference between II/1970 GNP projected in July 1969 using the old money supply data, and the forecast made in late September 1969 using the September 25 revision of the money supply data, was only $\$ 3.5$ billion, or 0.36 per cent. Using new money supply data, the total GNP figure projected for II $/ 1970$ was $\$ 966.4$ billion. 